\title{
The chips are down
}

\section{遺伝子チップ市場をめぐる二大企業の攻防}

Nature Vol.44 (256-257) / 16 November 2006

さまざまな要因が絡んだ複雑な疾患の根源を探ろうとする遺伝学者たちの願望が、遺伝子チップの市場を大きく摇り

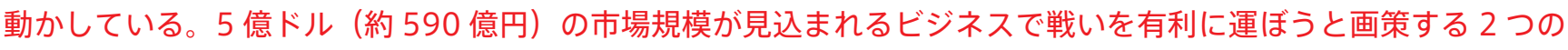
企業について、Meredith Wadman が取材報告する。

ウォール街アナリストの Elise Wang は 2006 年 10 月、遺伝子チップ製造業界の 「巨人」に関する投資家向け情報（カバレッ ジ）を、「売り」という明確に推奨する単 語で始めた。

彼女は、Affymetrix (アフィメトリク ス）社の株がすでに前年同時期に比べて ほぼ $50 \%$ 下がった株価で売買されてい る (グラフ参照) という事実にもかかわ らず、このアドバイスを提示したのだ。同 社は米国カリフォルニア州サンタクララに 本社を構え、遺伝子チップは同社の研究 者たちが 17 年前に開発したものである。 「Affymetrix 社の株価は、今以上に下がる 可能性があると私たちは考えており、それ は特に、遺伝子タイピング（遺伝子多型の 解析研究）市場において競争激化が続いて いるからだ」と、Citigroup のアナリスト であるWang は顧客にアドバイスした。

もちろん、ウォール街ではさまざま な意見が飛び交っており、UBS と Bear Stearns のアナリストたちは同じ 10 月に Affymetrix 社に対して、それぞれ中立の 評価と好意的な評価を下した。しかし、彼 らの評価がどうであれ、同社が新興のラ イバルであるIllumina (イルミナ) 社と の一騎打ちをせざるを得なくなったとみ るWang の予想に、異議を唱えるアナリ ストはほとんどいない。1998 年に創立さ れた Illumina 社はサンディエゴに本社を 置き、従業員数はAffymetrix 社の半分だ が、株価が最近 3 倍となり、時価総額では Affymetrix 社を上回っている。この勝負 は掛け金も儲けもばかにできないほど大き
い。両社は現在、バイオテク・ツールキッ ト市場において最大級の成長をとげる機会 をうかがい、勝負の真っ最中にある。

遺伝子チップはマイクロアレイまたは DNA チップともよばれ、シリコン製やガ ラス製、プラスチック製の基板の上に微 小な DNA プローブ分子を高密度に配置し たもので、これを使って多数の遺伝子が いつどのように発現するかを同時に調べ ることができる。現在の激戦地は、遺伝 子チップを使った遺伝子発現研究の分野 ではない。この分野はすでに多数の企業 が参入しており、そこではIllumina 社は マイナーな企業の1つにすぎない。この 分野では、Affymetrix 社のチップの売上 高が、競合企業すべての売上高の合計よ りも多いのである。だが、高密度遺伝子 タイピングという新規市場の参入企業は Affymetrix 社とIIlumina 社の 2 社のみ であり、2006 年の市場規模は控えめにみ ても 2 億 2500 万ドル（約 265 億円）で、 年間 $35 \sim 45 \%$ の成長が見込まれている。

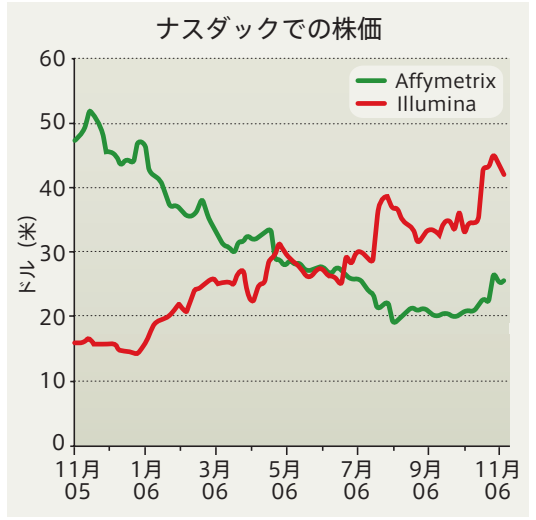

\section{ヒトゲノム解析の成功}

高密度遺伝子タイピングの実験では、あ る病気の患者とそうでない人といった条件 の異なる人々から採取した何百もの検体 の抽出 DNAを、マイクロアレイを使って 調べる。その目的は、各人の検体にある多 数の一塩基多型 (SNP、スニップ) を見つ け出すことだ。SNP とは、30 億塩基対か ら成るヒトゲノム内で個人によって異なる ごく少数の塩基である。この研究の目指す ところは、SNPの多型パターンを糖尿病 や喘息などのありふれた疾患と関連づけた り、薬剂治療に対する患者の反応と関連づ けたりすることだ。こうした実験に次々と 着手できるようになったのは、HapMap プロジェクトのおかげである。同プロジェ クトは、ヒトゲノム塩基配列に一般的な多 型パターンを初めて解析した大がかりな国 際共同研究であり、その成果は2005 年 10 月に公表された (The International HapMap Consortium Nature 437, 1299 -1320; 2005)。

そのころ、Affymetrix 社とIllumina 社は大急ぎで、HapMap プロジェクト が生み出した市場に資本投下していた。 2005 年の夏、Affymetrix 社は主力商 品である高密度遺伝子タイピング製品 「500K」を投入した。同製品は 2 個のチッ プを 1 セットとし、1つの検体について 50 万か所の SNP を確実に検出できる性 能をもつ。Affymetrix 社は、半導体チッ プ製造の技術を使って、25 万か所の SNP を特定するための DNA プローブをそれ ぞれのチップに固定し、「ゲノム規模の相 
関づけ研究のための、害用的で価格もお 手ごろな解決ツール」という触れ込みで、 この主力商品を投入した。

ところが、Affymetrix 社の 500K は すぐにつまずいてしまった。遺伝子タイ ピングを行うために不可欠なソフトウエ ア・アルゴリズムの深刻な欠陷など、製 造上および技術上の問題点が次々ともち 上がったためである。その結果、研究者 たちは大量のデータを失い、Affymetrix 社は不良チップの交換に忙殺された。

こうした問題は研究に「かなりの遅れ をもたらした」と、米国マサチューセッ ツ州ケンブリッジにあるブロード研究所 の人類遺伝学者 David Altshuler は語る。 同研究所の研究者たちは、Affymetrix 社 の欠陥アルゴリズム修正を手助けするの に数か月を費やした。「Affymetrix 社が 昨年出荷したチップのうち相当数が不良 品だった」と米国立加齢研究所の人類遺 伝学者である John Hardy は付け加えた。 「私のみたところでは、Affymetrix 社は Illumina 社に先んじようとして発売を急 ぎすぎたのだろう」。

Affymetrix 社の学術研究系事業部門 の副社長であるSean George によると、 500K に付随する諸問題は今や解決されて いるという。「当社が早めに500Kを出荷 したのは、これがエキサイティングな製品 であり、遺伝学研究にとって前例がないほ どの威力を発揮するからだ」と彼は話す。 「当社はすでに新しいアルゴリズムを発表 ずみであり、それ以降、当社のお客様には 完全製品版をご利用いただいている」。

しかし、2006 年5月に新アルゴリズ ムが発表されるまで、状況はあまり芳し くなかった。同年 1 月、Affymetrix 社の 顧客が 500Kの問題に苛立ちながら取り 組んでいたちょうどその頃に、Illumina 社が競合製品を発売した。それが単一チッ プからなるHumanHap 300Kであり、 続いてすぐに 550K-SNP 版と 650K-SNP 版が発売された。Illumina 社のチップは、 短いDNA 小片を固定した「ビーズ」を搭 載しており、各DNA 小片は特定のSNP に適合するようになっていて、HapMap プロジェクトで得られた知識が設計に活 かされているという長所があった。

BUSINESS NEWS

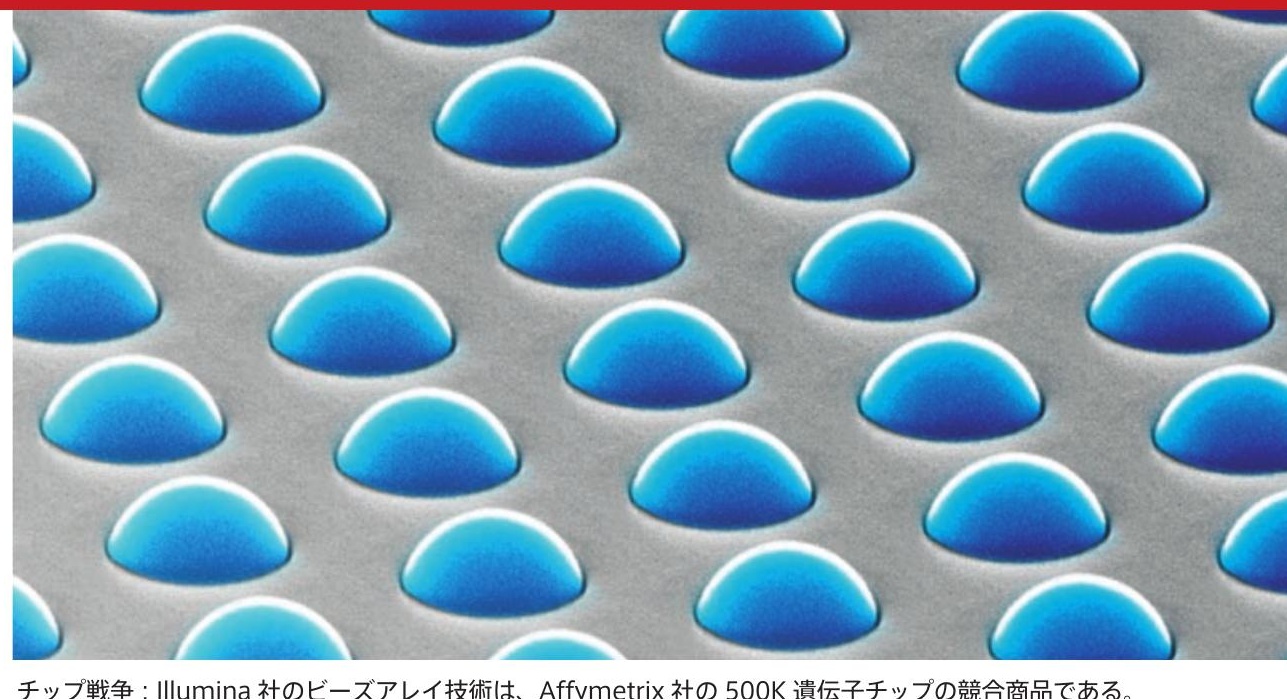

チップ戦争 : Illumina 社のビーズアレイ技術は、Affymetrix 社の 500K 遺伝子チップの競合商品である。

自由市場

2006 年の 4 月になって、Affymetrix 社 は3 か月前に投資家たちに提示した 2006 年の期待収益に関する指針を撤回すると いう、異例の手段を講じた。これは、収益 を予想することがもはや不可能なほど困 難な諸問題に、経営が直面していること のあらわれだった。自社の抱える諸問題に Illumina 社の新製品発売が追い討ちをか ける形となり、老舗である Affymetrix 社 は挽回に手間取ったのである。Illumina 社の最高責任者である Jay Flatley は、高 密度遺伝子タイピングに用いられるチップ の市場の最大 4 分の 3 までをすでに同社 が勝ち取ったと主張している。

この主張に対して、Affymetrix 社の George は異議を唱えている。そして、こ の数か月でAffymetrix 社は多少回復し つつあるようである。2006 年の夏、同社 は500Kチップセットを值下げして半額 の 250 ドル（約 3 万円）とし、チップ 1 個だけで動作する500K シリーズの新製 品を、2007 年早々に投入しようとしてい る。Illumina 社の競合種チップの価格は、 これよりも 30 ～50\%高いままである。 Affymetrix 社の動きは、その思惑どおり の結果をもたらした。現行の 500Kチッ プセットに対する顧客注文は 2006 年第 3 四半期で $90 \%$ 増しとなり、そのおかげも あって、Affymetrix 社の株価は 8 月 1 日 には最安值の 17.5 ドル (約 2000 円) だっ たのが 11 月 10 日には 26 ドル（約 3000 円）まで上昇した。

2006 年 9 月に Affymetrix 社は、 Framingham Heart Study（大規模集団 の長期追跡調査により心血管疾患の病因や
特性を探る米国の公的研究プロジェクト) から、心疾患·肺疾患 · 血液疾患と SNP との相関について 9000 以上の検体を解 析する契約を獲得した。一方で、Illumina 社は次々と契約を獲得しており、最近では、 Women's Genome Health Study（米国 の女性を対象として疾患相関性を探る官民 一体のゲノム解析プロジェクト) の一環と して 2 万 8000 検体の遺伝子タイピングを 行うために、Amgen 社により選定された。 Affymetrix 社は、新しい500Kに続い て 2007 年半ばまでに 100 万SNP チッ プを投入することを目指している。また 2007 年春には、デラウエア州の法廷で Illumina社と対決することになっている。 この裁判でAffymetrix 社は、いちばん の競合企業が自社の特許のうち 2 件の特 許権を侵害していると陪審員団に訴えよ うとするだろう。Illumina 社は、この裁 判で負ければ深刻な打撃を受けるはずだ。 Illumina 社のFlatleyは、自社の収益 (2006 年 11 月時点までで 1 億 2400 万 ドル [約 146 億円]、対して Affymetrix 社は 2 億 5100 万ドル [約 296 億円]) の 4 分の 3 が、係争中の 5 つの特許権の うち 1 つまたは複数を侵害したことで得 られたものだと見なされる可能性がある ことを認めている。

当面は、どちらの社ものんびり現状を 維持するつもりはないだろう。両社とも、 特定疾患の診断という分野に出現しつつ あるもう 1 つの遺伝子チップ市場を開拓 しようとするはずだ。一部のアナリスト たちの見方によれば、この分野はいずれ 年間 10 億ドル（約 1180 億円）もの市 場規模になる可能性がある。

www.nature.com/naturedigest

January 2007

volume 4

15

(C2007 NPG Nature Asia-Pacific 